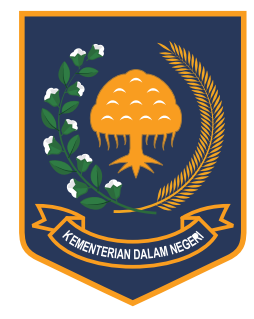

Jurnal Bina Praja 9 (1) (2017): 149-158

Jurnal Bina Praja

e-ISSN: 2503-3360 | p-ISSN: 2085-4323

Accreditation Number

735/AU2/P2MI-LIPI/04/2016

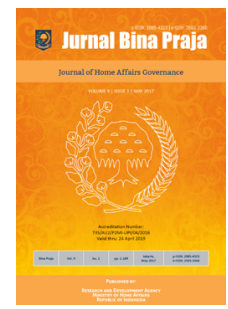

http://jurnal.kemendagri.go.id/index.php/jbp/index

\title{
EASTERn INDONESIA InCORPORATEd POLICY STRATEgy IN EASTERN INDONESIA
}

\author{
Teguh Narutomo * \\ Research and Development Agency \\ Ministry of Home Affairs \\ Jl. Kramat Raya No. 132, Central Jakarta
}

Received: 11 March 2017; Accepted: 12 May 2017; Published online: 31 May 2017

DOI: $10.21787 /$ jbp.09.2017.149-158

\begin{abstract}
This study is about the development gap in eastern Indonesia. This research is motivated by the existence of big problems that still faced by Indonesia up to now is the happening of development gap. The purpose of this research is the policy strategy in overcoming the gap between eastern Indonesia and West Indonesia region. This research uses the qualitative approach with discourse analysis method. Data collection method is done by triangulation technique of data source. Meanwhile, the data processing conducted by the researcher is data reduction. The result of this study is to provide an alternative policy that can be used and somewhat different from the mainstream which usually overcomes the gap by directly implementing the infrastructure development policy which until now based on the evaluation did not directly solve the problem, as evidenced by the many results of the construction of the stagnant infrastructure. Through this study, it is found that there are major issues that are more fundamental and often overlooked by policy makers. The main issues are grouped into three major groups of major issues, namely: Comprehensive Planning and Budgeting, Data and Information Effectiveness, and Professionalism of Civil State Apparatus.
\end{abstract}

Keywords: Development Gaps, Comprehensive Planning, Data Effectiveness, Professionalism of Civil State Apparatus

\section{INTRODUCTION}

This research is about the imbalance of interregional development in Indonesia. In Indonesia, at least known two regions namely Eastern Indonesia (KTI) and Western Indonesia (KBI). Two regions of Indonesia are more easily recognizable from the regional gap between the western and eastern regions.

The results of national economic development during the New Order government show that although nationally the national economic growth rate is on average high per year, at the regional level the development process during that time has created an imbalance of development resulting in a disparity between KBI and KTI. At least, during the data period of 1980-2011, Indonesia has the highest coefficient of variation (CV) of income in the world, which is 0.87 (Rosmeli, 2014).

Other data explained that in many aspects of economic and social development, KTI is far behind if compared to KBI. In 1975, KBI controlled $84.6 \%$ of national GDP with Java, which is only $9 \%$ of the total area, controlling $46.7 \%$ of national GDP and become the place to live for $63.2 \%$ of the population of Indonesia. More than three decades later, in 2013 KBI (Java and Sumatera) controlled $82 \%$ of national GDP by leaving KTI, which controlled only $18 \%$ (Prasetyo \& Firdaus, 2009).

The imbalance between sectors occurs because growth is not evenly distributed across all economic actors. Economic growth cycles have been largely supported by the modern sector (nontradable), such as the financial sector, services, real estate, transportation and communications, and trade/hotel/restaurant. The 2013 economic growth of $5.78 \%$ is supported by the non-tradeable sectors, such as the communications sector (grew $10.19 \%)$. This sector grew above the national average. In contrast, the real sectors (tradable), such as agriculture sector (3.5\%), industry (5.6\%), and mining, grow low (1.34\%) (BPS, 2016). The

\footnotetext{
* Corresponding Author

Phone : +62818103923

Email : narutomo1768@gmail.com
} 
imbalance in the growth of tradable versus nontradable sectors has serious implications as it relates to the distribution of cakes and economic surplus. The contribution of agriculture to national GDP in 2014 is only 14\%. In fact, this sector holds $41 \%$ of the total workforce. As a result, agriculture is increasingly involution and poverty in rural areas is also increasing.

The income gap between the population is increasingly worrisome. At least from BPS (2016) data, the income distribution shows the income portion of $40 \%$ of the people with the lowest income decreased, from $20.22 \%$ (2005) to $7.45 \%$ (2015). At the same time, the income of the top $20 \%$ of the population grew from $42.09 \%$ (2005) to $47.84 \%$ (2015). With the Gini ratio indicator, the trend is also the same. In the last decade, the Gini ratio has increased from 0.32 (2004) to 0.41 (2013) and then decreased to 0.4 by the end of 2015 . According to Credit Suisse's 2014 data, 1\% of the richest groups own money and property assets $50,3 \%$ of the total money and national property. From the above data, it shows that in the development of Eastern Region Indonesia, it still always has gaps with the Western Region of Indonesia. While in fact, not a few development policy programs allocated to Eastern Indonesia, but it still cannot overcome the gap that occurs between the two regions.

In that context, this research seeks to illustrate the various policy measures, both the things the government has undertaken and which have not yet been done on this development imbalance. In addition, this study also wants to see what factors make KTI farther away from KBI.

The locus of this study is covering the KTI. In accordance with Presidential Decree Number 13 of 2000 on the Eastern Indonesia Development Council, it is mentioned that the KTI region covers West Nusa Tenggara, East Nusa Tenggara, Irian Jaya, Maluku, North Maluku, North Sulawesi, Central Sulawesi, South Sulawesi, Southeast Sulawesi, East Kalimantan, South Kalimantan, Central Kalimantan, and West Kalimantan.

In addition, this research is also useful and has the right relevance to the main tasks and functions of the Ministry of Home Affairs (Kemendagri). In the Minister of Home Affairs Regulation Number 43 of 2015 , one of the functions of MoHA is the formulation, determination, and implementation of policies in the field of politics and general government, regional autonomy, regional administration development, fostering of government affairs and regional development, managing regional funding (Minister of Home Affairs Regulation Number 43 of 2015 on the Organization and Working Procedures of the Ministry of Home Affairs, 2015).

So far, there has been considerable research on gaps in Indonesia for example from OECD (2015).
One of the main obstacles faced by Eastern Indonesia is the logistics problem. Another study from the OECD on another study from the Asian Development Bank (Ginting \& Aji, 2015) mentions that poverty in Indonesia has dropped, $27 \%$ of the population lives just above the poverty line is amounted to 65 million, but these people are particularly vulnerable to return to poverty.

Unlike the above research, the SMERU Research (Suryahadi, Hadiwidjaja, \& Sumarto, 2012) assessed the relationship between economic growth and poverty reduction in Indonesia before and after the Asian financial crisis (AFC). Indonesia has a much slower post-AFC poverty reduction compared to the pre-AFC era. The trend of elasticity of poverty growth shows that the power of every percent of economic growth to reduce poverty has not changed much between the pre- and post-AFC periods. During this period, service sector growth was the largest contributor to poverty reduction in rural and urban areas.

Another issue is with the inequality of education. Azzizah (2015) examines the imbalance in KTI that Eastern Indonesia generally has a higher rate of uneducated people compared to Western Indonesia. In the study, the current state of education in terms of regional disparities between eastern and western provinces and to study the relationship between educational inequality and other related aspects, such as social and economic conditions.

In line with Azzizah is a research from Baransano, Putri, Achsani, \& Kolopaking (2016). The research is to find an analysis of the disparities in regional development and the factors affecting regional imbalances in the province of West Papua for the period of 2005 to 2014 . The results are based on the Williamson Index, indicating that the trend of inequality which fluctuated in regional development in West Papua Province tended to increase during that period.

From the above research and data, it can be seen that the impact of development disparity, besides disrupting the economic growth of Indonesia, is also more severe that it can disrupt the domestic stability of Indonesia. Meanwhile, the policy done with the mainstream of gradual infrastructure development has not significantly overcome the gap that occurred. Even in some places, the results of infrastructure development in eastern Indonesia are less utilized. Therefore, the issue of disparity is very important to be studied more deeply and involving all parties, both central government through the elements of Ministries/Non-Ministry Government Agencies related and local governments in Eastern Indonesia.

This study aims to determine the causes of the gap that occurs more deeply by evaluating the policies that have been done and looking for effective 
policy strategies in solving the problem of inequality in Eastern Indonesia, including to get an effective and comprehensive policy recommendations to reduce the gap in Eastern Indonesia. This study is also considered important and relevant because it sees the contemporary context in Indonesia, in which the concept of Nawa Cita by President Jokowi wants to bring back the country to provide prosperity to all citizens.

\section{METHOD}

This research was conducted in KTI. In accordance with Presidential Decree Number 13 of 2000 on the Eastern Indonesia Development Council, it is mentioned that the KTI region covers West Nusa Tenggara, East Nusa Tenggara, Irian Jaya, Maluku, North Maluku, North Sulawesi, Central Sulawesi, South Sulawesi, Southeast Sulawesi, Kalimantan East, South Kalimantan, Central Kalimantan, West Kalimantan.

This research uses qualitative research type while considering that the research using qualitative approach emphasizes its analysis on the inductive inference process as well as on the analysis of the dynamics of the relationship between the observed phenomena using scientific logic (Sugiyono, 2011) Meanwhile, this research approach uses discourse analysis.

Discourse analysis in communication science comes from Critical Marxist thought. Discourse analysis in media life also has a deep understanding. According to Fairclough (1995) discourse analysis is a discourse regarding the content of communication messages, some of which are text, such as speech texts, articles contained in newspapers, books. Meanwhile, in data processing, the researcher does a data reduction. As explained (Berg, 2001), data reduction is intended to draw attention to the focus of research needs, simplify, and transform raw data into a more manageable form. Data reduction is done by the researcher throughout this research process.

\section{RESULTS AND DISCUSSION}

This section describes the efforts made by the local government in realizing Innovation in the overview. This is different in Eastern Indonesia which looks bright orange which means it still has a small population. Papua, Nusa Tenggara, Sulawesi and Maluku only have $13.8 \%$ of the total population in Indonesia by 2013 , it is very much different in comparison with the population of people in Java Island only reaching $57.06 \%$. The existence of a large population and gather on the island of Java is not separated from the availability of centers of its great economic growth compared to Eastern Indonesia.

\section{A. Development Gap of Eastern Indonesia}

One way to measure the occurrence of economic disparities is to look at the distribution of GRDP values between provinces between 20082012. In 2012, there has been a high level of the gap, based on GDP at Current Prices (ADHB), where the contribution of GRDP is still dominated by Java-Bali Region and Sumatera Region. The contribution of GRDP from the Java-Bali region reaches $58.87 \%$ and Sumatra reaches $23.33 \%$ of the national economy. This is certainly very much different when compared with other areas in Eastern Indonesia, Kalimantan, Sulawesi, Nusa Tenggara, Maluku and Papua, which only reaches $17.4 \%$.

Meanwhile, to measure the occurrence of

Table 1.

GDP ADHB Distribution Value by Island in 2008-2012

\begin{tabular}{|c|c|c|c|c|c|}
\hline Region & 2008 & 2009 & 2010 & 2011 & 2012 \\
\hline Sumatra & 22.90 & 22.69 & 23.12 & 23.57 & 23.77 \\
\hline Java-Bali & 59.21 & 59.88 & 59.33 & 58.81 & 58.87 \\
\hline Kalimantan & 10.36 & 9.21 & 9.15 & 9.55 & 9.30 \\
\hline Sulawesi & 4.19 & 4.46 & 4.52 & 4.61 & 4.74 \\
\hline $\begin{array}{l}\text { Nusa Tenggara, } \\
\text { Maluku, and } \\
\text { Papua }\end{array}$ & 3.34 & 3.76 & 3.88 & 3.46 & 3.32 \\
\hline $\begin{array}{l}\text { Outside Java } \\
\& \text { Bali }\end{array}$ & 40.79 & 40.12 & 40.67 & 41.19 & 41.13 \\
\hline
\end{tabular}

Source: Bappenas, 2013 
Table 2.

Length of Road, Area, and Density of Roads between KBI and KTI

\begin{tabular}{|c|c|c|c|c|c|}
\hline \multirow{2}{*}{$\begin{array}{l}\text { Region of } \\
\text { Indonesia }\end{array}$} & \multicolumn{2}{|c|}{$\begin{array}{l}\text { Length } \\
\text { of Road }\end{array}$} & \multicolumn{2}{|c|}{ Total Area } & \multirow{2}{*}{$\begin{array}{c}\text { Density Ratio } \\
\text { of Road } \\
(\mathrm{km} / \mathrm{km} 2)\end{array}$} \\
\hline & (km) & $\%$ & $(\mathrm{~km})$ & $\%$ & \\
\hline KBI & 281,128 & 59 & 616,012 & 32 & 0,46 \\
\hline KTI & 197,540 & 41 & $1,294,920$ & 68 & 0,15 \\
\hline Total & 478,668 & 100 & 1,910,931 & 100 & 0,25 \\
\hline
\end{tabular}

inequality or regional disparities commonly used Williamson Index. The index consists of several groups: (1) low inequality with Williamson Index < 0.3; (2) moderate inequality rate with value between 0,3-0,7; And (3) high inequality with Williamson Index value $>0.7$. Based on the results of Bappenas analysis, the results of the Williamson Index nationally show that the development gap is very high, where interprovincial development is uneven from 2000-2012 with an average index of > 1 (Bappenas, 2013).

The good economic condition of the region is not only characterized by a rapid increase in economic growth, but also with better distribution of income (income distribution). Distribution of income is said to be good if the distinction between the rich and the poor is not too obvious. The level of the income distribution can be known by using the gini ratio coefficient. Gini ratio calculation results $(G)$ is seen from zero to 1 , with the general agreement that $\mathrm{G}<0.3$ is defined as low inequality, the range $0.3 \leq \mathrm{G} \leq 0.5$ is defined as moderate inequality and $\mathrm{G}$ $>0.5$ is interpreted as a high inequality.

Based on the above Gini Ratio measured in series from 2009 to 2013, it appears that Papua, West Papua, Gorontalo and DIY provinces have the greatest level of the income gap in Indonesia although still in the medium category. Furthermore, the gap with the category is going on in almost all other provinces.

Kompas R\&D in 2013 also conducted research and then released the results related to the Welfare Index in Indonesia. The index is assessed from the aspects of education, health, economy, and basic infrastructure, data diagrams processed from the Susenas, Suskernas, and PDRB issued by BPS. In the research, there is a gap in the level of welfare between Eastern Indonesia (KTI), such as Nusa Tenggara, Sulawesi, Maluku Islands, and Papua with Western Indonesia (KBI). KTI has an index that tends to be low with marked in red, whereas in KBI mostly green color which means having a high level of prosperity. In addition to the welfare index, the research also presents graph of Human Development Index (HDI) between 2004-2011. IPM is an important indicator to measure the success of development based on the movement of people in a country, given the HDI is calculated based on the movement of three components, namely: (1) life expectancy that represents the health sector, (2) the average number of schools that measure the achievement of development in education, and (3) GDP reflecting people's purchasing power.

The gap in the availability of road infrastructure between KBI and KTI can also be demonstrated through the Road Density Ratio indicator which describes the length of the road on every $1 \mathrm{~km} 2$ area. The ratio of road density in KBI reached 0.46 $\mathrm{km} / \mathrm{km} 2$, while KTI is $0.15 \mathrm{~km} / \mathrm{km} 2$. The significant difference in road density in both areas is due to the length of roads in the KBI covering $59 \%$ of the total length of roads in Indonesia, while the area only covers $32 \%$.

Based on data from the Ministry of PUPR, the length and density of the road network are still dominated by provinces in Sumatra and Java. While the provinces in Nusa Tenggara Island, Maluku, and Papua still have a long and smaller road density. Inequality in the availability of road infrastructure is one of the reasons why Eastern Indonesia has a smaller level of welfare, HDI, and GRDP, making it a relatively higher area than Java and Sumatra.

While the density of the road on the island scale, Java-Bali has the highest density $(0.89 \mathrm{~km} /$ $\mathrm{km} 2$ ), while the lowest density is found in the Papua region with a range of $0.06 \mathrm{~km} / \mathrm{km} 2$. The highest road density in KTI is in the Sulawesi region $(0.43$ $\mathrm{km} / \mathrm{km} 2$ ) which is aggregately higher than the density of roads in the Sumatra Island region of the KBI.

\section{B. Efforts to Overcome the Gap in Eastern Indonesia}

In the last few decades, there is an indication of the direction of development that tends to turn 
to capitalism and less in accordance with Pancasila and the 1945 Constitution. Of course, this must be straightened back to the people's economic system based on a mutual cooperation. Therefore, to realize the social justice for all Indonesian citizens, the KTI gap with KBI should be minimized.

In fact, many policy programs have been issued with more emphasis on infrastructure development programs in stages. But the result is still not significantly making changes to the gap KTI with KBI. In fact, it is also found that there is an infrastructure development that is apparently stagnant because it is less suitable to the needs of society and culture of the local community.

Based on the research conducted, it was found that there is a policy between which must be done first before the birth of infrastructure development policy. The policy is to establish an Acceleration Unit to Overcome the Gaps in Eastern Indonesia. The acceleration unit takes the following steps: (1) Comprehensive planning by involving all parties, including those with specific cultures, (2) Efforts to provide effective data and information so that all have open and guided data (3) Efforts to overcome the gap with the professionalism of the State Civil Apparatus (ASN), where the government through the bureaucratic apparatus as the spearhead in accelerating the policy program to overcome the GTI gap. This unit of acceleration was formed in an institution "Eastern Indonesia Incorporated".

In more detail that the 3 (three) major steps to overcome the gap of Eastern Indonesia are as described below.

\section{With Comprehensive Planning}

Policies made by the government so far, always using the same mainstream. The policy of overcoming the gap is always imposed on the imbalance of infrastructure development. In reality, this has often been a less successful policy in the achievement of follow-up programs, where infrastructure development often derived from "central" eyewear turns out to be underutilized by local people who tend not to be included in problemsolving.

This study offers alternative solutions that further empower the participation of the KTI community who are considered to be the most knowledgeable of their own needs. The policy approach offered is a comprehensive planning and development synergy approach, then by providing effective data and information for all stakeholders in eastern development, and forming a professional civil state apparatus to safeguard all policies that are created.

When viewed from the Comprehensive Synergy of Planning and Budget Development Comprehensive, in recent decades, there are indications of development direction that tend to capitalism and less in accordance with Pancasila and the 1945 Constitution. Of course, this should be straightened back to the people's economic system based on mutual cooperation. This is done through the restructuring and harmonization of legislation.

Furthermore, in the context of the regulatory framework that has been mandated as a series of development cycles, there are still many things that are less consistent and not optimal in implementation by all stakeholders in practice. In some places, there are also frequent inconsistencies between planning documents. It is, therefore, necessary to synchronize the process when preparing the planning documents, such as what documents should refer to what documents. One of the umbrellas of the synchronization process documents of Regional Development Planning is the Minister of Home Affairs Regulation No. 54 of 2010 on Implementation of Government Regulation No. 8 of 2008. However, technical instructions related to synchronization with the national planning document in particular not yet exist. Therefore, guidance is needed to maintain consistency of program/activity translation in RPJMN into RKP, RKP program/activity exploration into K/L Work Plan (Renja) up to Work Plan and Budget (RKA)$\mathrm{K} / \mathrm{L}$.

In accordance with Law no. 8 of 2015 on Amendment to Law no. 1 of 2015 on Stipulation of Government Regulation In lieu of Law no. 1 of 2014 on the Elections of Governors, Regents, and Mayors. With these rules, the process of synchronizing the planning documents needs to be done more rigorously, so that deviations do not occur from the planning process at each stage.

The concept of holistic-thematic, integrative and spatial development implementation needs to be followed up with integration in planning and budgeting documents by each Ministry/Institution and Local Government (province/district/city). Compliance between RPJMN - RPJMD, RKP and RKPD documents, and Renstra in each line of Government become a national technical policy indicator of operational that has been elaborated in planning and budgeting documents in each implementing unit.

In this case, the role of $\mathrm{K} / \mathrm{L} / \mathrm{D}$ is required in the assurance process that the concept of planning that has been made at the national scale can be understood and derived in their respective budgeting planning policy. Central Institutions (Bappenas, Ministry of Home Affairs, etc) and Local Government need to coordinate between sectors to achieve technical implementation agreement of each national priority. To optimize this requires a comprehensive mapping of each agency mandated to oversee the development process of the 
development plan and not just the formalities in the process of bilateral meetings in the RPJMN and RPJMD synchronization process).

Taking into account the prevailing conditions of today, it is also the time for the existing development planning system to be addressed. Every process and stage of development planning should be interrelated. Between the planning documents with each other is also expected synchronous. For example, the RT/RW document should be the reference for RPJMD.

Planning and budgeting also concentrate on the needs of the Ministry/Agency/Local Government (K/L/D) to support the implementation of its duties and functions only. Planning has not been oriented to synchronize the implementation of various priority programs of K/L/D to achieve national development objectives. This is what is not understood, agreed, and implemented by all stakeholders, so that national development has not reached the target optimally. The concept does not show significant performance towards the achievement of the goals and objectives of national development. Technically, the MoneyFollow Program concept also attempts to trim programs and nomenclature from units in Government agencies that are not clearly useful directly to the people. Therefore, the nomenclature of activities in each unit needs to clarify the purpose and objectives and the ultimate goal of the implementation of the activity (such as buying a net, buying seeds, building roads, etc.).

The process of planning and budgeting starting in 2017 is no longer based on the concept of Money Follow Function, but will be embraced the concept of "Money Follow Program" and even it should be "Money Follow Program Priority". This concept will be translated in the Holistic-Thematic, Integrative, and Spatial approach. Holistic means that coordination between multi-ministries and local government needs to be done to achieve the national priority target that has been determined. Integrated, which means that to support the achievement of national priorities, the integration of programs and strategic activities needs to be cross-sectoral. While spatial, it is understood that development undertaken in support of national priorities should consider needs based on location and integration with other sector development plans. Bappenas, in this case, will be a "System Integrator" to maintain the synergy of the development of various sectors in ensuring the achievement of national development goals.

The existence of unsynchronized and inconsistencies in development planning that occurred during this, one of them is caused by the dominance of political interests in the preparation of development planning documents. Often time, the members of the House of Representatives (DPR
/ DPRD) suggest new activities, though they have not been included in the RKP/RKPD documents when preparing budget documents. To overcome this, a rule or mechanism is needed to accommodate the new proposal, in such a way as to not interfere with the mature and ready-to-implement planning process.

The concept of developing from the periphery in an intact perspective is a form of affirmation to encourage economic activity which has been prioritized by the Government. Development from the periphery should be treated as a model of development that seeks to build linkages, harmony, and partnerships. If this model is implemented, the progress of rural areas, agriculture, micro and small and traditional businesses will also encourage urban areas, industries/services, medium and large enterprises, and modern economic activities.

In connection with this, development needs to begin by laying the foundations of an asymmetric decentralization policy. The form is to implement the policy of affirmative policy to areas that are still lagging behind. Classified areas including (a) border areas and outer islands; (b) disadvantaged and remote areas; (c) underdeveloped villages; (d) areas where the capacity of the government is insufficient in providing public services.

\section{Efforts to Provide Effective Data and Information}

If viewed from another aspect, the availability of Effective Data and Information remains the cause of the disparity. The provision of data and information is an early part of the planning stage that is crucial to the successful preparation of public documents. Quality data and information serve as a reference for policy formulation efforts in planning, monitoring the implementation, and evaluating programs and activities so that the target set can be achieved effectively. The results of data collection by governments, academics, research institutes and the business community (private) becomes a valuable asset for the development of information networks, statistics, and the development of information systems.

Despite the public disclosure of public information disclosure regulations, some K/L/D have not been motivated to publicize in accordance with the provisions. This is partly because at the policy level does not provide executive guidance. In addition, monitoring by the Central Information Commission (KIP) is still normative so that it gives an impression of only to fulfill administrative obligations.

Rules and policies that encourage channel awareness and access to public information have not yet been fully implemented by district/city governments. Public disclosure of information, 
especially in the aspect of information presentation of development budget has not felt to be a fundamental obligation for local government. The absence of certain legal sanctions makes central government regulations only a mere suggestion. Whereas on the other hand, citizens have already started to have concern for the importance of such information for their livelihood.

One Data data presentation from the 'private object' of K/L/D, to 'public object' requires a change of integrated information management paradigm by the Information and Documentation Management Officer (PPID). What has happened so far, the data provided by PPID as a data provider at the K/L/D level has not been integrated and represented in the One Data page. The publication of PPID information also varies from the completeness aspect as well as the details of the document. Of course, PPID data that is still scattered and stored on hundreds of websites and data centers, and various cyber security systems, require the convenience to monitor the completeness and validity of data. It requires a centralized serving portal, making it easier for monitoring and comparing data comprehensively.

Strengthening of data and information systems has a strategic role in supporting the achievement of development goals. The data and information management system are utilized by the K/L/D leadership and planners to generate policy and decision on the development plan, so as to achieve the intended target. Therefore, one of the prerequisites for the acceleration of regional development in overcoming regional disparities is the availability of an integrated database. Some basic issues related to the database will be described below.

The availability of data, for planning and analysis of development that is still limited, has not been updated, and even tends to not exist. This results in the process of planning and decisionmaking done by using irrelevant data.

The concept of One Data and Open Data has been proclaimed by the Government several years ago. This concept requires ongoing synergies from all $\mathrm{K} / \mathrm{L} / \mathrm{D}$ elements, with professional data management to provide uniform quality and facilitate monitoring of data collectively. In fact, in general, the One Data initiative has not been taken seriously by $\mathrm{K} / \mathrm{L} / \mathrm{D}$. Therefore, an effort is needed to increase the participation of $K / L / D$, considering the many benefits that can be obtained. The low participation also decreases the quality ranking of Open Data Indonesia. The World Wide Web Foundation shows Indonesia's ranking dropped from 36th position in 2014 to 40 in 2015. This reinforces the indication of the slow aspect of open data participation readiness, especially on K/L/D implementation variables and the impact (utilization) of data by business actors and communities. Therefore, it is necessary to have synergy and participation of K/L/D in Open Data, so that all data of $K / L / D$ is represented in one portal, induced and easily updated independently by each K/L/D. One Data \& Open Data benefits include enhancing business certainty for investors, enhancing government accountability, and transparency of government business processes, and can be a broad public-collective monitoring platform. Data centering allows each stakeholder to have a 'helicopter view' of all the data necessary for a development or investment. Data accuracy can be an assurance factor and reduce uncertainty costs for investors, especially risk and capital costs.

The use of data in One Data also provides broad benefits for strategic stakeholders such as journalists, academics, planners, NGOs, SMEs, and even the global public. Thus the entire development discourse, although multi stakeholder, all use the same data reference in its analysis, both in strategy discussions to operational implementation.

One Data Management can also reduce operational costs, optimize the potential of virtual resources, and improve the competence of IT human resources through joint expertise and knowledge sharing cooperation. For that, One Data needs to be reinforced with operationalization Open Data which requires improvement of sectoral data management of K/L/D which will be submitted to Open Data.

To accelerate and strengthen the provision of data, data processing and presentation of information in a complete and accurate and accountable, practical methods and comprehensive data presentation are needed to quickly reveal the resources of Natural Resources (SDA) potential. Up-to-date technology needs to be considered, for example, the use of Remote Sensing technology and Geographic Information System (GIS) in an integrated manner. GIS is currently very popular and is a computer-based system used to store and manipulate geographic information. GIS is designed for the collection, storage, and analysis of objects and phenomena in which geographical location is an important characteristic or that has the following four capabilities in handling geographically referenced data, including data input, data management (storage and data call), analysis, and manipulation Data, and data presentation. With this system, for example, the thematic maps that have been presented in graphical form, can be presented comprehensively in spatially based.

The development of the spatial database begins with standardization of data and the preparation of data using the rules of database compilation. This standard includes uniform format, structure, data file name settings, and elemental coding with simple and systematic rules. In addition to the uniform format of spatial data used for the development of spatial databases, standardization of data structures 
of spatial attributes and arrangement of data storage directories is also performed. The attribute is the reality of geography phenomena that exists on the surface of the earth. This data attribute contains information based on location and expressed in a particular coordinate system. Data standardization step aims to uniform, facilitate the identification of data so that more easily done search and data calls.

To facilitate this is expected one integrated unit (Information System Architecture) in charge of presenting information from data analysis in the database to policy makers. This unit consists of programmers who master IT and able to perform spatial database analysis in each department or agency, processing and presenting information to the leaders and the general public in a uniform. With this system, there is no duality of standards and systems that have the same theme in each agency.

More specifically for Eastern Indonesia (KTI), in order to produce and disseminate information properly and effectively in KTI, adequate ICT infrastructure, from the process of data collection, data processing, to the presentation of information. In addition, the development of natural resources sectors in KTI requires "mutual relationship" between stakeholders (government, private, and community elements), which is relationships that are mutually helpful and beneficial. To facilitate communication with various stakeholders both conventionally (face to face) and through virtual media (virtual), also needed support from ICT infrastructure. The cause of the lagging of ICT development in Eastern Indonesia is that during the development of information technology-based infrastructure, the majority is managed by private parties. Investments in the field of ICTs attract private attention to engaging. ICT-based providers or service providers, which are business-oriented, certainly consider market opportunities in place of telecommunication infrastructure development. That is why the development of ICT infrastructure so far is more concentrated in KBI market, while KTI gets less attention. Under these conditions, the Government should intervene to develop ICTs in KTI to facilitate access to information and to narrow the digital division between KBI and KTI.

\section{E. Efforts to Overcome the Gaps with Apparatus Professionalism}

Law Number 5 of 2014 on State Civil Apparatus confirms that the State Civil Apparatus (ASN) is a profession for civil servants (PNS) and government employees with employment agreements (P3K) working in government agencies. In terms of quantity, it is not proportional to ASN quality. This fact prompted the Government to implement policies to manage the amount, quality, and distribution of ASN in order to increase professionalism and streamline personnel expenditures, among others through moratorium policy on procurement of ASN in 2011 and 2015, and rationalization plan for civil servants. In 2016, the Government continues the moratorium program of civil servants from General Applicants who are exempted for positions in basic services (education and health) and certain technical positions that support 3 programs of Nawacita in the areas of health, education, and poverty alleviation. This underlies that the procurement of ASN for educators and health is still considered necessary because it is in line with the mandate contained in Nawacita.

In relation to civil servant rationalization plan, the Minister of PAN-RB has submitted this report to the President of RI through letter number B/1755/M.PANRB/05/2016 dated May 23, 2016, that currently, the number of civil servants reaches $5,517,136$ people with the average employee spending requirement Average of IDR707 trillion or $33.8 \%$ of the total APBN and APBD in 2015. In it, there are $1,906,306$ persons or $42.19 \%$ who occupy general functional positions/ implementers who do not have special competence as the demand is for more professional ASN. The large number of functional officials in the composition of national civil servants requires a review so that it requires mapping efforts according to qualifications, competencies, and performance in order to support the implementation of organizational tasks optimally

The arrangement of ASN for 3 years beginning in the first phase of 2016 is ASN mapping based on qualification, competence, and performance, while the second phase of 2017-2019 is the implementation of rationalization and golden handshake with a gradual reduction target of $1,000,000$ Civil servants. With the rationalization program and golden handshake, the future development of the organization must also be targeted for the procurement/filling of ASN human resources that can be more effective and efficient. Therefore, the procurement/replenishment of PPPK besides civil servants can be preferred, since the PPPK status does not contain the consequences of the budget for pensions so as not to burden the state finances.

The expected result of this arrangement is the realization of ASNs with qualifications, competencies, and performance with a total of $5-10 \%$ reduction in ASN employment expenditure on total APBN expenditures, as well as replacing ASNs who are entering the retirement age limit with higher quality ASNs.

Furthermore, in order to guarantee the quality and professionalism of civil servants in the framework of developing a modern and worldclass bureaucracy in 2025, the structuring of HR 
Apparatus is done through a series of strategies, among others (1) ASN Planning as Required, (2) Transparent and Free Recruitment of KNK, (3) Creating ASN Professionalism.

Currently, the Ministry of PAN-RB has reformed the CPNS recruitment/recruitment system from general applicants, with basic competence test material (TKD) compiled by experts from state universities representing all parts of Indonesia as well as selection done openly and transparently by using CAT system. Through the reform of the selection system, it is expected to be able to guarantee the quality, objectivity, transparency, and free of corrupted practices in order to obtain CPNS. Expected employees of character, integrity, and professional to be hired. Moreover, this has brought public confidence back to the Government in terms of CPNS selection.

The placement of officials, especially in KTI, which is incompatible with the background of science and competence still occurs in bureaucratic organizations. In other words, it does not reflect "The Right Man on The Right Job". There are still many structural positions in districts and municipalities filled by the functional staff of teachers, Head of Puskesmas held by a Bachelor of Economics, and others.

Government and politics are actually two sides of a coin that cannot be separated from one another. Politicsand government in the context of a democratic country cannot stand alone and complement each other. Politics is often misunderstood by so many people that it can have negative connotations. But in fact, it happened because the person or the political actors themselves do not understand the meaning of politics, so embedded in the understanding of many people that politics is merely for the sake of power alone. It is then applied in government organizations, including local government. The regional head who is the PPK (Personnel Officer) in the area is often improperly using the authority. The "like and dislike" factor still occurs in the background of the political problem itself. To minimize this, it may require special provision to the Head of Region, both Governor/Vice Governor, Regent/Vice Regent and Mayor/Vice Mayor when newly served the management of civil servants. Associated with ASN management, many facts show that ASN is not free from political intervention, even some cases of civil servants in secret and openly plunge in the political area by participating in a campaign for certain candidates. In the process of Election of Regional Head (Pilkada), they are like eating simalakama fruit, inevitably some ASN elements will be involved directly or indirectly plunge as a successful team. When acting as a successful team, they hope to have an opportunity to occupy positions and to get facilities and other benefits as a reciprocal effort to help the winning of the Head of Region. The hope cannot be denied considering the position of the head of a very strategic area and dominates the various policies of regional employment. Head of Region has the authority to arrange organizational structure, propose promotion, filling a position, giving of service facility, allowance, honor, to set reward to a civil servant. When they occupy positions, regional civil servants are not free to be free, they are often subject to certain political pressures and targets related to their position and title.

Relevant institutions such as the Ministry of PAN-RB, BKN, and the ASN Commission already need to formulate policies related to the already widespread political intervention or politicization of ASN starting at the stage of nominating the head of the region up to the election. Therefore, there need to be strict protection measures and sanctions for those who violate the rules that will be determined by the relevant agencies.Through the policy program developed by Eastern Indonesia Incorporated Institution, the policy can be made to ASN professionalism in KTI so that it can accelerate and immediately overcome the GTI disparity. The central government through the agency provides policy innovations specifically used in Eastern Indonesia. In its implementation, can be used the ASN in KTI or ASN everywhere focusing on building and overcoming the gap.

\section{Conclusion}

From the result of the discussion in the previous chapter, THE red thread in this study is that the KTI gap impact on socio-economic on each province. Inequality of income on PDRB also impacts due to inequality in development in Indonesia. In addition, the issue of equity is also a strategic issue, in which the imbalance between development in KTI and KBI continues to widen. The policies that have been carried out need to be evaluated to get the expected results to be able to resolve the gaps immediately.

Alternative solutions offered from the results of this study are some solutions that are somewhat different from the usual mainstream. The main step is to establish an Eastern Indonesia Incorporated institution that performs 3 (three) main points by doing (1) Addressing the Gap with Comprehensive Planning by including all stakeholders, especially from stakeholders in the regions up to the Central Government through Bappenas and the Ministry/ Institution. (2) In addition, the fundamental issues in the development of sustainable KTI should also pay attention to the presentation of data and information quality as a basic policy that will be determined. All stakeholders building KTI must have the same data, One Data and Open Data access. (3) Then to operationalize all policies and overcome the gap between KTI and KBI, required the existence 
of civil apparatus of state professionalism. With ASN professionalism, it is hoped that there will be synergy between the planning structure and the availability of data that can be directly operational and felt the benefit by all parties, especially the KTI.

\section{ACKNOWLEDGEMENT}

The researcher would like to thank the Head of the State Administration Institution who facilitated the Reform Leader Academy IV education and training program and assisted in the creation of this research, which is the result of the thinking of all the informants who participated in the Training and represented the region as well as the Ministry/ LPNK and supported by the facilitators, namely Prof. Wisnu, Prof. Mardi, Prof. Raka and Prof. Ancok, and Adi Suhendra, M.Sosio from Balitbang Ministry of Home Affairs who participated in refining the results of this study.

\section{REFERENCES}

Azzizah, Y. (2015). Socio-Economic Factors on Indonesia Education Disparity. International Education Studies, 8(12), 218-230. http://doi. org/10.5539/ies.v8n12p218

Baransano, M. A., Putri, E. I. K., Achsani, N. A., \& Kolopaking, L. M. (2016). Analysis of Factors Affecting Regional Development Disparity in the Province of West Papua. Journal of Economics and Development Studies, 4(2), 115-128. http://doi.org/10.15640/jeds. v4n2a10

Berg, B. L. (2001). Qualitative Research Methods for the Social Sciences. (S. L. Kelbaugh, Ed.) (4th ed.). California State University.

Fairclough, N. (1995). Critical Discourse Analysis:
The Critical Study of Language. London: Longman Group Ltd.

Ginting, E., \& Aji, P. (2015). Summary of Indonesia's Economic Analysis (ADB Papers On Indonesia No. 2). ADB Papers on Indonesia (Vol. 2).

Law of the Republic of Indonesia Number 5 of 2014 on State Civil Apparatus, Pub. L. No. 5 (2014). Indonesia.

Minister of Home Affairs Regulation Number 43 of 2015 on the Organization and Working Procedures of the Ministry of Home Affairs, Pub. L. No. 43 (2015). Indonesia.

OECD. (2015). Survei Ekonomi OECD Indonesia.

Prasetyo, R. B., \& Firdaus, M. (2009). Pengaruh Infrastruktur pada Pertumbuhan Ekonomi Wilayah di Indonesia. Jurnal Ekonomi Dan Kebijakan Pembangunan, 2(2), 222-236. Retrieved from http://repository.ipb.ac.id/ handle/123456789/53638

Presidential Decree Number 13 of 2000 on the Eastern Indonesia Development Council, Pub. L. No. 13 (2000). Indonesia.

Rosmeli. (2014). Dampak Belanja Daerah Terhadap Ketimpangan Antar Daerah di Provinsi Jambi. Jurnal Paradigma Ekonomika, 9(1), 85-93. Retrieved from https://online-journal. unja.ac.id/index.php/paradigma/article/ view $/ 2315$

Sugiyono. (2011). Metode Penelitian Kuantitatif, Kualitatif, dan R\&D. Jakarta: Alfabeta.

Suryahadi, A., Hadiwidjaja, G., \& Sumarto, S. (2012). Economic Growth and Poverty Reduction in Indonesia Before and After the Asian Financial Crisis. Bulletin of Indonesian Economic Studies, 48(2), 209-227. http://doi.org/10.1080/0007 4918.2012.694155 